\title{
The Concept of Spiritual Humanism in Mulia Sadra's Philosophi: an Analysis Study of the Existence of Modern Humans
}

\author{
Hidayatul Qoriah, Nurul Khair* \\ Sekolah Tinggi Filsafat Islam (STFI) Sadra Jakarta \\ Email*: Nurulkhair97@gmail.com
}

\begin{abstract}
This paper is a review of Mulla Sadra's thought library about the concept of spiritual humanism and its significance to human existence in the modern era. This paper aims to find out the meaning, principles, and nature of humanism in Mulla Sadra's views through his main work entitled al-Asfar al-Arba'ah and some research on Mulla Sadra's philosophical thinking. By using philosophical descriptive analysis, it can be concluded that the concept of Mulla Sadra's humanism is studied and explored through the discourse of the soul. The implication, humans know and realize the existence of immaterial aspects in their existence is perfect. In addition to knowing that there is a material aspect to human existence, the humanism concept in Mulla Sadra's view is to criticize the views of western philosophers, such as Jean Paul Sartre and Fredrich Nietzsche who view human existence based on material awareness. As a result, human existence is seen through the material side. The implication, human awareness is limited. In the modern era, the majority of people understand their existence as offered by western philosophers, so that the majority of people do not have awareness in realizing and knowing their existence, as they should. In addition, the views of western philosophers on material awareness in human existence cause freedom of will. Freedom of will in the western view causes dehumanism, because it prioritizes emotional aspects and passions in increasing human existence. The results of this paper to provide solutions in raising awareness of human existence, especially regarding the meaning, principles and nature of humanists in the modern era. The more aware humans are of humanist meaning and nature, the higher human existence will be. The implication, humans can reach the level of perfection in themselves without any restrictions. From these various explanations, the author hypothesizes that the concept of spiritual humanist Mulla Sadra can increase human existence and provide solutions to the crisis of human existence in the modern era.
\end{abstract}

Keywords: Humanist, Spiritual, Meaning, Nature, Existence

\section{INTRODUCTION}

The issue of humanism is one of the issues that developed after the first world war. (Yunida Sofiana, Pengaruh Revolusi Industri terhadap Perkembangan Desain Modern (Jakarta: Humaniora, 2014), vol. 5, no. 2, hal. 833). The main factor developing the issue of humanism is the high level of poverty and human death. The high level of poverty and death is based on human freedom to determine the direction of their lives independently. As a result, human values have declined. The implication, humans live with various miseries and limitations of various rules imposed on him. (Yunida Sofiana, Pengaruh Revolusi Industri terhadap Perkembangan Desain Modern, vol. 5, no. 2, hal. 834)

For example: Humanity is forced to work and is subject to various problems to achieve a goal outside of itself (Frederick Engels, Tentang Das Kapital Marx (Bandung: Bed's Renaissance, 2007), hal. 2) As a result, humans work against their will. The implication, the value and position of humans has decreased in external life. Humans are not seen based on their existence, but material (something outside of themselves). Some western philosophers, such as Friedrich Nietzsche and Jean Paul Sartre put the humanist concept as a serious discourse in his philosophical system to criticize the practice of dehumanist-the opposite of the word humanist-.

The failure of the first world war has given suffering to human life, especially the problem of existence (Toshihiko Izutsu, Concept and Reality of Existence, vol. III, hal. 27) Friedrich Nietzsche in the work of Human All too Human explains the human will is something fundamental in his life. Existently, humans can determine the direction of their lives to see things in reality. (Friedrich Nietzsche, Human All-Too-Human (Edinburgh: Morrison \& GIBB Limited, 1910), hal. 15) The view of human freedom is also confirmed by Friedrich Nietzsche in his work Thus Spake Zarathustra that man longs for a freedom in himself. A freedom will lead humans to the truth of existence (Friedrich Nietzsche, Thus Spake Zarathustra (Pennslyvania: A PennState Electronic Classic Series, 1999), hal. 61-62) Friedrich Nietzsche tries to describe human freedom as the main goal in world life, as is his character. (Jainul Arifin, Konsep Kehendak Manusia dalam Pemikiran Nietzsche dan Mu'tazilah (Yogyakarta: Universitas Islam Negeri Sunan Kalijaga, 2014), hal. 3) In achieving the main goal, humans can will freely without any restrictions. Humans can achieve the perfection of human values through free will. Free will implies the strength of human existence in reality. The more human 
will freely, the stronger his existence. (Jean Paul Sartre, Seks dan Revolusi (Yogyakarta: Narasi, 2015), hal. 4)

Friedrich Nietzsche's view is identical with Jean Paul Sartre's view of the humanism concept. The humanist concept of Jean Paul Sartre can be known through his theory of existence. Jean Paul Sartre explained the meaning of existence is the way humans on earth. (Harun Hadiwijono, Sari Sejarah FIlsafat Barat 2 (Yogyakarta: Kanisius, 1980), hal. 157) Jean Paul Sartre explained that the basis of the way humans exist is consciousness, through human consciousness can understand the meaning of life (the way they are) and break free from conditions that imprison human existence (quiddity). (Jean Paul Sartre, Existenstialism and Humanism (London: Eyre Methuen LTD, 1973), hal. 11) Based on this view, Jean Paul Sartre criticized Descartes thought "I think, then I exist". (Jean Paul Sartre, Existenstialism and Humanism, hal. 23) The view established by Descartes has ignored human existence and prioritized quiddity. (Setyo Wibowo, Filsafat Eksistensialisme Jean Paul Sartre (Yogjakarta: Kanisius, 2011), hal. 75) Jean Paul Sartre is of the view that the act of thinking is a human quantity does not work without human existence. Humans can determine how to exist through an awareness. (T.Z. Levine, Petualangan Filsafat: Dari Socrates ke Sartre (Yogjakarta: Penerbit Jendela, 2002), hal. 340) Awareness helps humans to increase their existence in reality. Humans can intend, both thinking and acting based on material awareness. (Bernard Delfgaauw, Filsafat Abad 20 (Yogjakarta: Tiara Wacana Yogya, 2001), hal. 146) The higher the awareness of human matter, the stronger its existence. The implication, humans can will freely based on their existence without any outside influence.

Jean Paul Sartre and Friedrich Nietzsche understand human consciousness from the material aspect as a fundamental reality in human life. Jean Paul Sartre and Friedrich Nietzsche's views are based on materialistic epistemology and western empirical logic which views matter as an object of knowledge. (Mohammed Bidhendi, Causation According to Hume and Allämah Tabātabā' ', hal.119) Materialistic paradigms and empirical logic affect human knowledge of their existence. Humans view that human values are based on the body, so humans act based on instincts and instincts that involve their sensory powers. (Setyo Wibowo, Filsafat Eksistensialisme Jean Paul Sartre (Yogjakarta: Kanisius, 2011), hal. 75) The implication is that the offer of western philosophers is dehumanist. Humans do not want based on their desires, but are influenced by something outside of themselves - lust and emotional. All actions and wills are based on lust and desire implies the loss of spiritual aspects in human life. Humans act like animals who seek delicacy and pleasure by involving their instincts and instincts. Instincts and instincts are the primary foundation of consciousness of existence, as is the view of western philosophers.
Humans can free will through the power of instincts and instincts. The stronger human instincts and desire, the more aware of their material existence. (Murtadha Mutahahhari, Bedah Tuntas Fitrah: Mengenal Jati Diri, Hakikat, dan Potensi kita (Jakarta: Citra, 2011), hal. 1617) The paradigm implies a moral crisis in human life. Humans will regardless of good and bad values. (Immanuel Kant, Critique of Pure Reason (Newyork: Cambridge Universirty Press, 1998), hal. 4) All wills are seen to fulfill his satisfaction and pleasure. As a result, the human will does not describe its existence as a human but rather describes its existence as an animal. (Murtadha Mutahahhari, Manusia Seutuhnya (Jakarta: Sadra Press, 2012), hal. 213) The implication is that free will in western bidding does not increase human values.

In order to overcome the various problems above, a solution is needed as a form of attention to the lack of western offerings related to humanist concepts. Basically, western philosophers ignore the spiritual aspects of human existence. As a result, humans are trapped in the delicacy and enjoyment of matter. The delicacy and enjoyment of matter affects the deterioration of aspects of human morality, so that humans cannot reach the perfection of existence in themselves. This paper seeks to present the concept of spiritual humanist Mulla Sadra with the aim of knowing the influence of spiritual aspects in enhancing human values. In the discourse of human philosophy, the core of human values is based on the actuality of the soul as the essence of human perfection. (Muhammad Utsman Najati, Jiwa dalam Pandangan Para Filosof Muslim, hal. 193) The actuality of the soul is transcendent, so it cannot be achieved through material awareness but through immaterial awareness. Humans need spiritual aspects to increase immaterial awareness. Immaterial awareness will affect the human will to increase the existence of humanity. (Seyyed Hossein Nasr, Ensklopedi Tematis Filsafat Islam (Bandung: Mizan, 2003), hal. 298)

\section{METHOD}

This paper aims to find out the meaning, principles, and nature of humanism in Mulla Sadra's views through his main work entitled al-Asfar al-Arba'ah and some research on Mulla Sadra's philosophical thinking. By using philosophical descriptive analysis, it can be concluded that the concept of Mulla Sadra's humanism is studied and explored through the discourse of the soul. The implication, humans know and realize the existence of immaterial aspects in their existence is perfect. In addition to knowing that there is a material aspect to human existence, the humanism concept in Mulla Sadra's view is to criticize the views of western philosophers, such as Jean Paul Sartre and Fredrich 
Nietzsche who view human existence based on material awareness.

\section{RESULT AND DISCUSSION}

Mulla Sadra in his work entitled Hikmah al-Muta'aliyah fi al-Asfar al-Aqiyah al-Arba'ah, holds that the natural nature of humans is the existence of potential quasusbtansi - moving towards perfection. (Mulla Sadra, AlHikmatuh al-Mutālīyah fì al-asfār al-aqliyah al-arba'ah (Bairut: Dar Ehia al-Tourath al-Arabi, 2002), jilid 3, hal. 66) Humans can achieve perfection through the actuality of the soul. Basically, the soul is a substantive immaterial in human existence. (Ibrahim Kalin, Knowledge in Later Islamic Philosophy (Newyork: Oxford University Press, 2010), hal. 118) All actions and human will cannot happen without a soul. On the other hand, please note that the soul in its potential has a dependence on the body (Murtadha Mutahhari, Filsafat Hikmah: Pemikiran Mulla Sadra (Bandung: Mizan, 2002), hal. 10). The human soul cannot exist as it should before heading towards actuality. Humans need various actions to perfect their souls, one of which is selfpurification. (Sayyid Yahya Yatsribi, Agama dan Irfan (Jakarta: Sadra Press, 2012), hal. 92). The process of self-purification can be obtained through spiritual aspects. The higher the spiritual aspects of humans, the more actual the human soul. The actuality of the soul leads humans to perfection, so that humans can enjoy and enhance their values through the process of selfpurification. (Mulla Sadra, Al-Hikmatuh al-Mutālīyah $f \grave{\imath}$ al-asfār al-aqliyah al-arba'ah, jilid 2, hal. 15). Muhammad Abdul Haq in his research entitled Mulla Sadra Concept of Subtantial Motion explains that humans have potential in themselves. Naturally, human potential moves towards the process of actuality through self-purification (pure form). The purer the human self, the more actual potential. (Muhammad Abdul Haq, Mulla Sadra Concept of Subtantial Motion (Islamabad: Islamic Research Institut, 2013), hal. 80).

The actuality of the soul's potential describes the independence of the soul in the body. Basically, every soul experiencing actuality will release its dependence and give effect to the body in reality. (S.M. Khaemenei, Mulla Sadra's: Transcendent Philosophy (Tehran: SIPRIn, 2004), hal. 66) The actions of the body will follow the existence of the soul. All human actions are caused by his soul, so that humans will not do outside the influence of the perfection of the soul. (Muhammad Utsman Najati, Jiwa dalam Pandangan Para Filosof Muslim (Bandung: Pustaka Hidayah, 2002), hal. 76-77) The perfection of the soul directs humans to act logically and positively for themselves, so that these actions describe the actions of human beings in reality. (Kholid Al-Walid, Perjalanan Jiwa Menuju Akhirat (Jakarta: Sadra Press, 2012), hal. 77). Every human being can feel peace and happiness in acting without a sense of alienation and sadness. Basically, Mulla Sadra's explanation seeks to increase the value of morality as one of humanity's values, after experiencing various corruptions in reality. Thus, it can be seen that human values in humanist discourse require spiritual aspects to increase human existence in reality. Without the spiritual aspects of man can not be willing in his existence as a human being. On the other hand, it is known that Mulla Sadra's view is a new breakthrough in humanist discourse. Humans cannot attain immaterial awareness without the actuality of the soul. (Fakhri Mashkoor, Menjelajah Semesta Iman (Jakarta: Al-Huda, 2011), hal. 138). The actuality of the soul can be achieved through self-purification. The implication of self-purification is to increase human existence freely and consciously. Humans will based on their common sense, thus affecting human will in reality. (Ibahim Amini, Dunia Lain: Rukun Iman Kelima (Jakarta: Al-Huda, 2009), hal. 31-32). The healthier human beings, the more perfect human existence in reality. (Muhammad Iqbal Mansulrudin, Kebahagiaan Spiritual Berbasis Filsafat Ibn Sina (Jakarta: STFI Sadra, 2017), hal. 41)

Based on the explanation above, researchers propose a temporary conjecture that the humanist concept does not neglect the spiritual aspects. In addition, the concept of spiritual humanists in the perspective of Mulla Sadra has an influence on human existence. In this study, the author examines the humanist concept in Hikmah alMuta'aliyah Mulla Sadra as a critical study of western views. Friedrich Nietzsche and Jean Paul Sartre are philosophers who lived in the 19th century. Meanwhile, Mulla Sadra is a philosopher who lived in the 16th century. In studying the humanist concept of Mulla Sadra, the writer refers to Mulla Sadra's work entitled Hikmah al-Muta'aliyah fi al- Asfar al-Aqliyah alArba'ah. Whereas the humanist concept in the view of western philosophers, researchers refer to Thus Spake Zarathustra, Human All-Too-Human, Existentialism and Humanism, and Being and Nothingness.

\section{Meanings and History of West Humanism}

Etymologically the word humanist comes from Latin, which is humanus and rooted the word homo means human. (A. Mangunhardjana, Isma-Isme dari A sampai Z (Yogyakarta: Kanisius, 1997), hal. 93). In the Kamus Besar Bahasa Indonesia (KBBI), the word humanist means the principle of humanity (1), someone longs for a good lifestyle (2). (Tim Penyusun, Kamus Besar Bahasan Indonesia (Jakarta: Balai Pustaka, 2001), hal. 533). In the order of western philosophy and Islam, the humanist concept is examined through an existentialist approach (Toshihiko Izutsu, Concept and Reality of Existence (Tokyo: The Keio Institute of Cultural and Linguistic Studies, 1971), vol. III, hal. 26). According to Heidegger in his book titled Being and Time explains existentialists is a way to determine his existence in reality. In humanist discourse, Heidegger's explanation can be understood that humans can determine the 
existence or pattern of life freely in reality (Martin Heidegger, Being and Time (Newyork: Harper \& Row Publisher, 1962), hal. 33). Heidegger's philosophical view was made clear through Jean Paul Sartre's concept of freedom of existentialism philosophy that freedom is something absolute for human beings. Every human being wants freedom in will, because freedom is a fact for humans to obtain their own meaning or humanity (Firdaus Yunus, Kebebasan dalam Filsafat Jean Paul Sartre (Gorontalo: Al-Ulum, 2011), hal. 270).

From the explanation above, it can be concluded that humanism is the way humans determine the will and actualize all human potential, so that humans know the nature of themselves. In this sense, it can be seen that humanists try to uphold human values through freedom of will. In its history, humanists were motivated by the lack of human knowledge of their potential and values. In classical Greek times, some philosophers such as Plato and Socrtes tried to explain the ideal human characteristics (Sumasno Hadi, Konsep Humanisme Yunani Kuno dan Perkembangannya dalam Sejarah Pemikiran Filsafat (Banjarmasin: Universitas Lambung Mangkurat, 2012), hal. 110-111). Ideal human characteristics aim to find out the values, principles and human potential. In the Middle Ages, the humanist concept was renewed by some church thinkers, such as St. Aqustinus and St. Thomas Aquinas who views humans as having an immanent and transcendent existence. (Sumasno Hadi, Konsep Humanisme Yunani Kuno dan Perkembangannya dalam Sejarah Pemikiran Filsafat, hal. 111) Medieval understanding was influenced by the rapidly developing understanding of the church. However, the humanist concept in the Middle Ages did not experience significant development, because the church members used the humanist concept to achieve personal goals. (Thomas Sowell, Marxism Philosophy and Economic (New York: William Morrow and Company, 1985), hal. 36) As a result, humanists in ecclesiastical offerings do not actualize their potential and know their principles. For example: Churchmen encourage people to carry out various activities without being based on their own will and potential. Humans work to get a reward outside of themselves.

The humanism concept in the Middle Ages was adopted and renewed in the Enlightenment Century (1617 centuries). Some philosophers, such as Rene Descartes, Spinoza, and Leibniz, study humanist concepts through a rationalist approach. Rene Descartes in the system of rationalist philosophy explains human reason is a parameter of truth that guides humans to achieve awareness of existence in reality. (Misnal Munir, Pengaruh Filsafat Nietzsche terhadap Perkembangan Filsafat Barat Kontomporer (Yogyakarta: Jurnal Filsafat, 2011), vol. 21, no. 2, hal. 139) The more humans use their minds, the more humans reach the truth. Truth will guide man to know the nature and principles of himself. Descartes's offer and the philosophers of rationalism caused humans to start ignoring religious aspects by referring to common sense. The offer of enlightenment philosophers was developed by modern philosophers (19-20 centuries), such as Jean Paul Sartre and Friedrich Nietzsche who understood the humanist concept as human freedom. Freedom is something that is real to human life. Every human being expects a freedom to determine the way they are without any outside influence. Jean Paul Sartre and Friedrich Nietzsche view human existence as a basic principle that does not depend on something, such as religion and reason. (Setyo Wibowo, Filsafat Eksistensialisme Jean Paul Sartre, hal. 89) Jean Paul Sartre and Friedrich Nietzsche's offer influenced the paradigm of modern society in viewing humanity's principles and values. Humanity acts freely to actualize its existence without being limited by various things in reality. (Mohammed Bidhendi, Causation According to Hume and Allāmah Tabātabā' '̄ (Tehran: SIPRIn Publication, 1999), hal.118119)

From the various explanations above, it can be seen that the history of the humanist concept from classical Greek to modern cannot be released with human curiosity in finding out the principles, potential, and nature of man. Thinkers from classical to modern times put the humanist problem as something serious, even placing the humanist problem in their system of thought. On the one hand, various western views related to the humanist concept are based on material awareness, so that all human principles, potentials, and values are viewed through the materialistic side. Such as: Humans can determine their will to work, as their bodily actions. As a result, immaterial or immanent will is ignored by western thinkers. The implication, human freedom in the western view does not reflect human to know the principles, potential, and values in him. (Muhammad Iqbal Mansulrudin, Kebahagiaan Spiritual Berbasis Filsafat Ibn Sina (Jakarta: STFI Sadra, 2017), hal. 41) Thus, the western offer to know human values does not become a wise foundation. On the one hand, it is known that the humanist concept in the western offer causes dehumanism in human life, consequently the humanist concept in the western view does not help humans to know and know themselves. In the following discussion, the author will explain the phenomenon of western offer to the existence of modern society.

\section{Impact of Western Humanism Concept on Human Values in the Modern Era}

The humanism concept in the view of Jean Paul Sartre and Friedrich Nietzsche has influenced the paradigm of modern humans to understand the values of their lives. Jean Paul Sartre and Friedrich Nietzsche in their philosophical systems explain human values depend on material awareness to act and free will to determine the values of humanity in reality (Bertrand Russell, Sejarah 
Filsafat Barat (Yogjakarta: Pustak Pelajar, 2002), hal. 1024). For example: Ain acts and thinks to fulfill the values of her existence. The values of Ain's existence are material which is influenced by the five senses which capture the variety of matter in reality. As a result, Ain's existence depends on his five senses and material forces to explain his human values. The implication is that human values are limited by the five senses and material strength - something outside of human existence - which causes human values to be material. (Frederick Copleston, A History of Philosophy: Hobbes to Hume, vol. 5, hal. 33-34). As a result, the humanist concept in the western offer does not increase human values, but the humanist concept in the western offer creates dehumanism in human life. Humans are increasingly far from human values, due to the influence of the power of matter by looking at materials is a necessity for him to fulfill the values of existence in him. (Friedrich Nietzsche, Beyond Good and Evil (United State: $1^{\text {st }}$ World Library, 2003), hal. 12).

Furthermore, the humanist concept in the western view not only influences the paradigm of modern humans in viewing matter as fundamental to their lives, but also influences human actions and will. Sensory power as a medium achieves human values in itself. Sensory power involves the power of lust and emotional power implies the loss of spiritual aspects in human life. Humans act like animals who seek delicacy and pleasure by involving their instincts and desire. (Murtadha Mutahahhari, Bedah Tuntas Fitrah: Mengenal Jati Diri, Hakikat, dan Potensi kita (Jakarta: Citra, 2011), hal. 1617). Instincts and desire are the primary foundation of consciousness of existence, as is the view of western philosophers. (Bertrand Russell, Sejarah Filsafat Barat, hal. 867). Humans can free will through the power of instincts and desire. The stronger human instincts and desire, the more aware of their material existence. The paradigm implies a moral crisis in human life. Humans will regardless of good and bad values. All wills are seen to fulfill his satisfaction and pleasure. (Immanuel Kant, Critique of Pure Reason (Newyork: Cambridge Universirty Press, 1998), hal. 4). As a result, the human will does not describe its existence as a human but rather describes its existence as an animal, such as; the act of promiscuity that causes humans to act freely without any restrictions to meet the sensations in him. (Murtadha Mutahahhari, Bedah Tuntas Fitrah: Mengenal Jati Diri, Hakikat, dan Potensi kita, hal. 17). Acting freely causes a high level of criminalization in human life, such as rape, theft, violence, and so on to achieve delicacy and pleasure. As a result, humans do not achieve something ideal in themselves, but achieve something outside of themselves. The implication is that humans do not know their values that cause human existence to decline.

Thus it can be seen that the humanist concept in western offerings has had a negative impact on the paradigm of modern humans to understand human values. Humans are not looking for something substantive (values, principles, and their identity), but are looking for something outside of themselves compensation, pleasure, and delicacy-. (Frederick Copleston, A History of Philosophy: Hobbes to Hume, vol. 5, hal. 18). The attitude of looking for something outside of the self causes humans to be unable to describe their true identity independently, but depends on matter and sense power. As a result, humans see their existence through material things. On the one hand, it is known that the humanist concept in the western view does not provide a solution to the historical development of human life. Basically, classical Greek thinkers through the Middle Ages offered humanist concepts to enhance human understanding of the nature and values of humanity. (Friedrich Engels, Ludwig Feuerbach and The End of Classical German Philosophy (Stuttgart: Vorlag Von Dietz, 1995), hal. 13-14). On the contrary, the humanist concept in the view of modern thinkers does not explain the human aspect significantly and comprehensively, but rather explains freedom as an object of humanist studies in the modern era. As a result, humans do not act according to their human values, but are based on sensations, pleasures, and delicacies which are qualities outside of human beings. In order to restore human understanding of the humanism concept, an axis of thought is needed as a solution to the obscurity of western humanism concepts. (Daya Negri Wijaya, "Kontrak Sosial Menurut Thomas Hobbes dan Jhon Locke" (Yogjakarta: Jurnal Sosiologi Pendidikan Humanis, 2016), hal. 186). In the history of Islamic philosophical thought, some philosophers, such as Mulla Sadra have studied the humanism concept in a spiritual approach. The concept of spiritual humanism in the view of Mulla Sadra is a solution to the weakness of the humanist concept in the western view.

\section{Spiritual Humanism Concept in Sadra's Philosophy}

One of the main discussions of humanists is to make people aware of their values and principles with the aim of humanizing. The aim of the humanist discussion is in harmony with the discussion of philosophy which aims to find a truth in reality, especially the truth of human existence. (Siti Farikhah, Perbandingan Teori Gerak Menurut Sadr al-Din al-Syirazi dan Issac Newton (Semarang: Institute Agana Uskan Begeru Walisongo, 2013), hal. 55). In philosophical discourse, especially Islamic philosophy, the truth of human existence is examined through a spiritualist approach. The spiritualist approach in Islamic philosophy presents unique offers, such as the soul, the movement of human inner potential, and human reason. (Muhammad Abdul Haq, Mulla Sadra Concept of Subtantial Motion, hal. 80). One madrash of Islamic philosophy, Hikmat Muta'aliyah focuses his philosophical system on the humanist problem through unique offers.

The humanism concept in Sadra's philosophical system can be known through the concept of Harakat alJauhariyah (substantial movement). The concept of 
Harakat al-Jauhariyah in Mulla Sadra's thought is a process of moving human substance from a potential stage to actuality. (S.M. Khaemenei, Mulla Sadra's: Transcendent Philosophy, hal. 68). The substance in Mulla Sadra's philosophy can be interpreted as the core, principle, and nature of human beings called the soul. The soul in the view of Mulla Sadra is immaterial which always moves freely from potential to actuality without any material influence on reality. The concept of Harakat al-Jauhariyah in Mulla Sadra's philosophy can be analyzed through classical Greek humanist discourse and the time of the church. The humanism discourse in the classical Greek view and the viewer tried to offer human characteristics to be ideal, immanent, and spiritual. Human characteristics are ideal, immanent, and spiritual can be known through the concept of Harakat al-Jauhariyah in the philosophy of Mulla Sadra. Mulla Sadra explained that the human soul is always experiencing a movement from potential towards actuality that implies the perfection of human existence. (Reza Akbarian, Trans-Substantial Motion and Its Philosophical Consequences, vol. 2, hal. 176; Lihat juga Yanis Eshots, Substantial Motion and New Creation in Comparative Context, hal. 82). The perfection of human existence influences the actuality of two human minds, namely the theoretical sense (ma'rifat al-haq) and practical reason (ma'rifat al-khair). (Ibn Sina, al-Mabda wa al-Ma'ad (Tehran: Tehran University Press, 1998), hal. 109). The actuality of theoretical reason can be described through the immanent knowledge of humans towards themselves and the actualization of practical reason can be described through human will to determine how to be in reality.

The actuality of theoretical reason and practical reason reflects mankind to achieve the truth and eternal perfection of his existence. Theoretical reason is the initial gate to reach the truth and eternal perfection of human existence. Theoretical reason serves to analyze human existence and material reality. Analysis of reality and human existence reflects the human paradigm to understand the difference between reality and human existence, so that humans can obtain truth values about their existence and outside themselves.( Ibrahim Kalin, Knowledge in Later Islamic Philosophy: Mulla Sadra on Existence, Intellect, and Intution (New York: Oxford University, 2010), hal. 89-90). Knowledge related to human existence and material existence influences the human perspective to look for something substantive for his perfection. Humans will avoid various values that do not support the process of refinement and the actuality of their existence. On the one hand, it is necessary to know that the actuality of theoretical reason is achieved through the actulity of the human soul. Humans can activate their souls through the process of selfimprovement in reality. The process of self-improvement is the key to opening the gate of the actuality of the human soul. The process of self-improvement can be achieved through human awareness about the urgency of spiritual awareness, so that spiritual awareness is a wise method for activating human potential and values. (Mulla Sadra, Al-Hikmatuh al-Mutāī̄yah fì al-asfār alaqliyah al-arba'ah, jilid 3, hal. 66). The more often a person increases his spiritual awareness, the more actual the potential and values of one's humanity.

Furthermore, the process of perfecting theoretical reason influences human will in reality. Basically, humans act and will based on their knowledge, all actions and human will are systematically acted by human practical reason, so that humans act freely and systematically in reality, without any limitations on the existence of matter in reality. (Ibahim Amini, Dunia Lain: Rukun Iman Kelima, hal. 32). Humans can freely determine how to be in reality, so that humans can know the potential and values in themselves independently. On the one hand, it is known that practical reason in Mulla Sadra's philosophy seeks to limit human emotional and lust power, so that humans do not act based on sensation, delicacy, and pleasure. The implication, humans act to fulfill their human values, as human existence is not controlled by delicacy, sensation, and enjoyment-is something outside of human beings-. The escape of human existence from everything outside of him builds the ideal human character in the paradigm of modern humans. (Muhammad Iqbal Mansulrudin, Kebahagiaan Spiritual Berbasis Filsafat Ibn Sina, hal. 41) The ideal human character can be proven through human attitudes independent of material existence. Humans do not act continuously without a long thought process, but humans will act and will as human values. The implication, humans can achieve a happiness and perfection of existence in their lives in the modern era. Humans can build wise individual, family, and community relationships within a social frame, so that all attitudes of abuse, violence and crime can be avoided in the modern era. (Ibn Sina, al-Mabda wa al-Ma'ad (Tehran: Tehran University Press, 1998), hal. 109)

Thus, it can be seen that the concept of Harakat alJauhariyah in Mulla Sadra's philosophy is a wise solution to restore human values through the actuality of the soul, theoretical reason, and practical reason based on self-purification. The actuality of the soul is the process of releasing human existence from the existence of the body-matter-. Humans do not depend on the existence of matter - something outside of themselves -, so that humans do not look at their material existence, but rather see their existence substantively through the actuality of theoretical reason and practical reason. Theoretical reason reflects the human paradigm to realize the differences in the existence of themselves and outside themselves. The difference between human existence and something other than itself implies that humans can know the values and nature of themselves, so that humans can increase their existence with the aim of understanding existence that is higher than him. As a 
result, humans can perfect themselves gradually through graded awareness (Taqi Mizbah Yazdi, Buku Daras Filsafat Islam (Jakarta: Sadra Press, 2010), hal. 154). The more a human increases theoretical reason, the more he draws closer to and realizes a higher existence. On the one hand, the actuality of theoretical reason influences human practical reason. Human practical reason influences human actions and actions, so that modern humans do not act and will based on delicacy and pleasure, but humans act based on self-improvement in reality (Mulla Sadra, Al-Hikmatuh al-Mutālīyah fì alasfār al-aqliyah al-arba'ah, jilid 3, hal. 67). Thus, it can be seen that the spiritual humanist concept in Mulla Sadra's philosophy is a wise breakthrough to raise awareness and restore human existence that has been misunderstood by western thinkers. On the one hand, the spiritual humanist concept in Mulla Sadra's philosophy seeks to restore the humanist meaning in the philosophical discussion, so that Mulla Sadra's offer becomes an explanation of the humanist concept for the modern human paradigm.

\section{CONCLUSION}

The more aware humans are of humanist meaning and nature, the higher human existence will be. The implication, humans can reach the level of perfection in themselves without any restrictions. From these various explanations, the author hypothesizes that the concept of spiritual humanist Mulla Sadra can increase human existence and provide solutions to the crisis of human existence in the modern era.

\section{REFERENCES}

Ali, Mohammad. Memahami Riset. Jakarta: Pustaka Cendikia Utama, 2011.

Amini, Ibahim. Dunia Lain: Rukun Iman Kelima. Jakarta: AlHuda, 2009.

Amini, Ibrahim. Self Building. Qum: Bahman Press, 1997.

Arifin, Jainul. Konsep Kehendak Manusia dalam Pemikiran Nietzsche dan Mu'tazilah. Yogyakarta: Universitas Islam Negeri Sunan Kalijaga, 2014.

Bakker, Anton dan Achmad Charris Zubair. Metodologi Penelitian Filsafat. Yogjakarta: Kanisius, 1990.

Bidhendi, Mohammed. Causation According to Hume and Allāmah Tabātabā'̄i. Tehran: SIPRIn Publication, 1999.

Delfgaauw, Bernard. Filsafat Abad 20. Yogjakarta: Tiara Wacana Yogya, 2001.

Engels, Frederick. Tentang Das Kapital Marx. Bandung: Bed's Renaissance, 2007.

Farikhah, Siti. Perbandingan Teori Gerak Menurut Sadr al-Din al-Syirazi dan Issac Newton. Semarang: Institute Agana Uskan Begeru Walisongo, 2013.

Gimball, Charles. Kala Agama Jadi Bencana. Bandung: Mizan, 2003.
Hadi, Sumanso. Konsep Humanisme Yunani Kuno dan Perkembangannya dalam Sejarah Pemikiran Filsafat. Banjarmasin: Universitas Lambung Mangkurat, 2012.

Hadiwijono, Harun. Sari Sejarah FIlsafat Barat 2. Yogyakarta: Kanisius, 1980.

Haq, Muhammad, Abdul. Mulla Sadra Concept of Subtantial Motion Islamabad: Islamic Research Institut, 2013.

Heidegger, Martin. Being and Time. Newyork: Harper \& Row Publisher, 1962.

Indrajaya, Ferdinand. Refleksi Pandangan Nietzsche terhadap Moralitas dan Kepentingan Diri. Jakarta: Humaniora, 2010.

Izutsu, Toshihiko. Concept and Reality of Existence. Tokyo: The Keio Institute of Cultural and Linguistic Studies, 1971.

Kaelan. Metode Penelitian Agama Kualitatif Interdisipliner. Yogjakarta: Paradigma, 2010.

Kalin, Ibrahim. Knowledge in Later Islamic Philosophy. Newyork: Oxford University Press, 2010.

Kant, Immanuel. Critique of Pure Reason. Newyork: Cambridge Universirty Press, 1998.

Khaemenei, S.M. Mulla Sadra's: Transcendent Philosophy (Tehran: SIPRIn, 2004.

Kung, Hans. Atheis Sigmund Freud: Ketegangan Radikal Psikologi dan Spiritual. Yogyakarta: Labirin, 2017.

Levine, T.Z. Petualangan Filsafat: Dari Socrates ke Sartre. Yogjakarta: Penerbit Jendela, 2002.

Mangunhardjana, A. Isma-Isme dari A sampai Z. Yogyakarta: Kanisius, 1997.

Mansulrudin, Muhammad, Iqbal. Kebahagiaan Spiritual Berbasis Filsafat Ibn Sina. Jakarta: STFI Sadra, 2017.

Mashkoor, Fakhri. Menjelajah Semesta Iman. Jakarta: Al-Huda, 2011.

Moran, Dermot. Introduction to Phenomenology. London: Routledge, 2002.

Munir, Misnal. Pengaruh Filsafat Nietzsche terhadap Perkembangan Filsafat Barat Kontomporer. Yogyakarta: Jurnal Filsafat, 2011.

Mutahhari, Murtadha. Filsafat Hikmah: Pemikiran Mulla Sadra. Bandung: Mizan, 2002.

Mutahhari, Murtadha. Manusia Seutuhnya. Jakarta: Sadra Press, 2012.

Mutahhari, Murtadha. Bedah Tuntas Fitrah: Mengenal Jati Diri, Hakikat, dan Potensi kita. Jakarta: Citra, 2011.

Muzairi. Kebebasan Manusia dan Konflik dalam Pandangan Eksistensialisme Jean Paul Sartre. Yogjakarta: Universitas Islam Negeri Sunan Kalijaga, 2012.

Najati, Muhammad, Utsman. Jiwa dalam Pandangan Para Filosof Muslim. Bandung: Pustaka Hidayah, 2002.

Nietzsche, Friedrich. Human All-Too-Human. Edinburgh: Morrison \& GIBB Limited, 1910.

Nietzsche, Friedrich. Thus Spake Zarathustra. Pennslyvania: A Penn State Electronic Classic Series, 1999.

Pals, Daniel L. Seven Theories of Religion. Yogyakarta: IRCiSoD, 2012.

Piliang, Yasraf, Amir. Bayang-Bayang Tuhan: Agama dan Imajinasi. Jakarta: Mizan, 2011.

Russell, Bertrand. Sejarah Filsafat Barat. Yogyakarta, Pustaka Pelajar, 2016.

Sadra, Mulla. Al-Hikmatuh al-Mutālīyah fì al-asfār al-aqliyah alarba'ah. Bairut: Dar Ehia al-Tourath al-Arabi, 2002. 
Saputra, Happy. Konsep Epistemologi Mulla Shadra. Yogyakarta: UIN Sunan Kalijaga, 2016.

Sartre, Jean, Paul. Existenstialism and Humanism. London: Eyre Methuen LTD, 1973.

Sartre, Jean, Paul. Seks dan Revolusi. Yogyakarta: Narasi, 2015.

Sativa. Empirisme, Sebuah Pendekatan Penelitian Aristektural. Yogyakarta: Insersia, 2011.

Semiawan,Conny R. Metode Penelitian Kualitatif. Jakarta: PT. Grasindo, 2010.

Shafii, Mohammad. Psikoanalisis dan Sufisme. Yogjakarta: Campus Press, 2004.

Sholihah, Al-Hikmah al-Muta'aliyah: Pemikiran Metafisik Eksistensialistik Mulla Sadra. Mataram: Universitas Islam Negeri Mataram, 2010.

Sina, Ibn. al-Mabda wa al-Ma'ad. Tehran: Tehran University Press, 1998.

Sofiana, Yunida. Pengaruh Revolusi Industri terhadap Perkembangan Desain Modern. Jakarta: Humaniora, 2014.

Sowell, Thomas. Marxism Philosophy and Economic. New York: William Morrow and Company, 1985.
Suseno, Franz, Magnis, Pemikiran Karl Marx: Dari Sosialisme Utopis ke Perselisihan Revisionisme. Jakarta: Gramedia, 2003.

Tim Penyusun, Kamus Besar Bahasan Indonesia. Jakarta: Balai Pustaka, 2001.

Usman, Husaini dan Purnomo Setiady Akbar, Metode Penelitian Sosial. Jakarta: Bumi Aksara, 2014.

Walid, Kholid, Al. Perjalanan Jiwa Menuju Akhirat. Jakarta: Sadra Press, 2012.

Wibowo, Setyo, Filsafat Eksistensialisme Jean Paul Sartre. Yogjakarta: Kanisius, 2011.

Yatsribi, Sayyid, Yahya. Agama dan Irfan. Jakarta: Sadra Press, 2012.

Yazdi, Taqi, Mizbah. Buku Daras Filsafat Islam. Jakarta: Sadra Press, 2010

Yunus, Firdaus. Kebebasan dalam Filsafat Jean Paul Sartre. Gorontalo: Al-Ulum, 2011.

Yussafina, Diana, Mella. Eksistensialisme Jean Paul Sartre dan Revelansinya dengan Moral Manusia. Semarang: Universitas Islam Negeri Walisongo, 2015. 